\title{
SUMMARY OF CONCEPTUAL REPOSITORY ANALYSES AND EVALUATIONS AND IN SITU HEATER EXPERIMENTS FOR FY 1977
}

Submitted To

\author{
Office of Waste Isolation \\ Oak Ridge, Tennessee \\ operated by \\ Union Carbide Corporation \\ Nuclear Division \\ for the
}

Energy Research and Development Administration

By

Gary D. Callahan

November 21, 1977

This report was prepared by RE/SPEC InC., under Subcontract No. 89Y-22303C with Union Carbide Corporation, Nuclear Division, under Contract No. W-7405-eng-26 with the Energy Research and Development Administration. The subcontract was administered by the Office of Waste Isolation, Union Carbide Corporation, Nuclear Division.

\section{RE/SPEC INC.}

P. O. BOX 725 - RAPID CITY, S. D. 57701 - 605/343-7868 


\section{DISCLAIMER}

This report was prepared as an account of work sponsored by an agency of the United States Government. Neither the United States Government nor any agency Thereof, nor any of their employees, makes any warranty, express or implied, or assumes any legal liability or responsibility for the accuracy, completeness, or usefulness of any information, apparatus, product, or process disclosed, or represents that its use would not infringe privately owned rights. Reference herein to any specific commercial product, process, or service by trade name, trademark, manufacturer, or otherwise does not necessarily constitute or imply its endorsement, recommendation, or favoring by the United States Government or any agency thereof. The views and opinions of authors expressed herein do not necessarily state or reflect those of the United States Government or any agency thereof. 


\section{DISCLAIMER}

Portions of this document may be illegible in electronic image products. Images are produced from the best available original document. 


\title{
SUMMARY OF COMCEPTUAL REPOSITORY ANALYSES AND
}

\section{EVALUATIONS AND IN SITU HEATER EXPERIMENTS FOR FY 1977}

\author{
Submitted To \\ Office of Waste Isolation \\ Oak Ridge, Tennessee \\ operated by \\ Union Carbide Corporation \\ Nuclear Division \\ for the \\ Energy Research and Development Administration

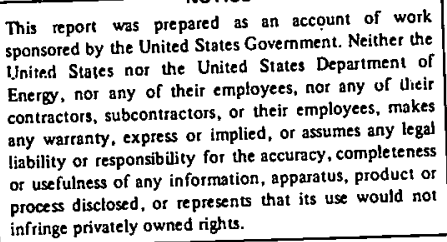 \\ (oves, nor any of dicir \\ Energy, nor any of their enp or their employees, makes \\ any warranty, express or implied, or assumes any legal \\ liability or responsibility for the accuracy, completeness \\ process disclosed, or represents that its use would not \\ infringe privately owned rights.
}

Gary D. Callahan

of

RE/SPEC InC.

P. O. BOX 725

Rapid City, South Dakota

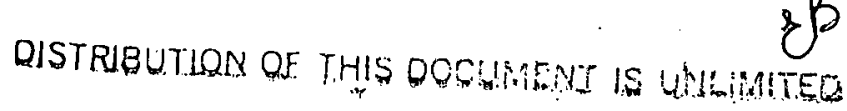

November. 21, 1977

This report was prepared as an account of work sponsored by the United States Government. Neither the United States nor the Energy Research and Development Administration, nor any of their employees, nor any of their contractors, subcontractors, or their employees, makes any warranty, express or implied, or assumes any legal liability or responsibility for the accuracy, completeness of usefulness of any information, apparatus, product or process disclosed, or represents that its use would not infringe privately owned rights. Any mention of trade names in this report j.s for reference purposes only and should not be construed as any manner of endorsement. 


\section{FOREWORD}

This report was prepared under a subcontract with Union Carbide Corporation, Nuclear Division, an ERDA contractor. The subcontract was administered by the Office of Waste Isolation and is part of the National Waste Terminal Storage (NWTS) Program. The principal objective of the NWTS Program is to provide facilities in various deep geologic formations at multiple locations in the United States which will safely dispose of commercial radioactive waste, which must be delivered to a Federal Repository for terminal storage. Some of the expected wastes produce both heat and radioactivity. This situation leads to many unique problems in rock mechanics. This report addresses a particular problem relative to the Rock Mechanics Program.

The overall objective of the OWI Rock Mechanics Program is to predict the response of a rock mass hosting a waste repository during its construction and operation, as well as the post-operational phase. The operational phase is expected to be approximately 20 years while the post-operational phase will last until the repository no longer poses any potential hazard to mankind, a period that may last several hundred thousand years. The Rock Mechanics Program is concerned with near field effects on mine stability as well as far field effects relative to the overall integrity of the geologic containment of waste.

In order to accomplish the objectives of the Rock Mechanics Hrogiram, numerical simulation, laboratory (including bench scale), and field studies are under way. The laboratory and field studies provide input to the numerical simulations and also the opportunity for validation of the predictive capabilities of the computer codes. Ultimately, the computer codes will provide the predicted response of the host rock mass and thereby form an essential part of the overall Rock Mechanics Program. The contents of this report include $R E / S P E C^{\prime} s$ work efforts from October 1, 1976 through September 30, 1977. Various topics involving analytical/numerical simulations, rock mechanics testing, in situ testing, and general supportive activities are included. A basic discussion of each individual task is included with pertinent results and conclusions with reference to the detailed study reports. 


\section{TABLE OF CONTENTS}

PAGE

1. INTRODUCTORY REMARKS

2. GLOBAL REPOSTTORY ANALYSES 3

3. STRUCTURAL ANALYSIS OF PROGRESSIVELY. MINED SOLUTION CAVITIES . 7 IN SALT

4. STRUCTURAL SIMULATION OF THE ROOM-AND-PILLAR MINING SYSTEM AT THE JEFFERSON ISLAND SALT MINE

5. SHORT-TERM DEFORMATION IN SALT REPOSITORIES 13

6. QUAST-STATIC AND CREEP TESTING $\quad 17$

7. DESIGN FABRICATION AND IMPLEMENTATION OF CREEP TESTING · 21 APPARATUS

8. TECHNICAL ASSISTANCE TO OWI ON IN SITU HEATER EXPERIMENT 22 DESIGN

9. INSTALLATION OF AN. IN SITU HEATER EXPERIMENT

10. REVIEW/WORKSHOP ON THE ROCK MECHANICS ASPECTS OF RADIOACTIVE 24 WASTE DISPOSAL IN GEOLOGICAL FORMATIONS

11. FINITE-ELEMENT COMPUTER CODE USER MANUALS

LIST OF REFERENCES 
Comparison of Temperatures at the Outer Radius of Various Repository Models Subjected to a Gross Thermal Loading of $150 \mathrm{Kw} /$ Acre of 10 Year Old Spent Fuel for Various Models. Subjected to a Gross Thermal Loading of $150 \mathrm{Kw} /$ Acre of 10 Year Old Spent Fuel a Spherical Cavity the Various Models

\section{LIST OF TABLES}

The discussions included herewith are the result of an assemblage of many hours of work involving many $R E / S P E C$ personnel. The author is appreciative of the overall guidance provided by Dr. Paul F. Gnirk. Guidance of the laboratory, field, and engineering endeavors under the direction of Messrs. Francis D. Hansen, Leo L. Van Sambeek, and Joe $L$. Ratigan, respectively, along with their contributions and review herein are greatly appreciated. The supportive efforts and enthusiasm of Dr. Arlo F. Fossum and Messrs. Ralph A. Wagner, John $D$. Osnes, Henry Waldman, Randall J. Stickney, Kirby D. Mellegard, Leslie A. Wagner, Wesley $F$. DeYonge, and Daniel M. Schiermeister must also be recognized. The typing and careful preparation of this manuscript by Ms. Julie S. Annicchiarico is appreciated. 


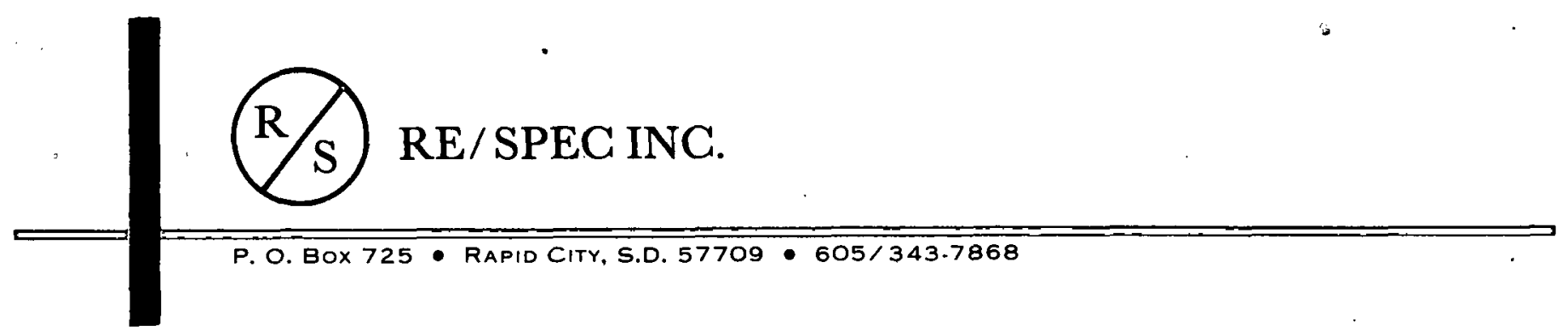

November 21, 1977

PROJECT SUMMARY REPORT RSI-0060

TO: $\quad$ Office of Waste Isolation

P. O. BOX Y

Oak Ridge, TN 37830

Attn.: Dr. James E. Russell

Dr. William C. MCClain

FROM: Mr. Gary D. Callahan

RE/SPEC InC.

P. O. BOX 725

Rapid City, SD 57709

SUBJECT: Summarization of the Experimental and Analytical/Numerical Activities of RE/SPEC InC. for the Time Period October 1, 1976 through September 30, 1977 (Union Carbide Corporation, Nuclear Division Subcontract No. 89Y-22303; RSI/001000/FY77).

\section{INTRODUCTORY REMARKS}

During the time period October 1, 1976 through September 30, 1977, RE/GPEC InG. has completed and initiated several tasks related to various aspects of the National Terminal Waste Storage Program. The specific tasks, involving generally rock mechanic's efforts, included analytical/numerical simulations of repository concepts utilizing the finite-element method, quasi-static and creep testing of laboratory specimens, and in situ experimentation. The major portion of the overall work effort has been devoted to the analytical/numerical simulations, with the laboratory testing program acting as a support facility in developing material properties and constitutive relations from various salt formations.

The analysis efforts have involved a parametric scoping of the global temperature fields and the potential for global thermal fracturing around repository facilities. Previous analyses in this regard ${ }^{1-9}$ were local in the sense that they were performed for regions about the waste emplacement drillholes and around the room and pillar configurations. Further analysis activities involved an extension of previous 
work ${ }^{10}$ related to the structural analysis of progressively mined solution cavities, completion of the simulation of the structural behavior of the Diamond Crystal Salt Company/Jefferson Island Mine, and assessing short-term room closures for repository configurations in salt. Each of the above analysis efforts were, in general, evaluated in conjunction with rock properties data obtained through the laboratory testing program. Contract negotiations with Akzona/International Salt Company for use of the Avery Island (AI) Mine facilities were not completed until late August, 1977. Thus, the major work effort regarding the in situ testing has involved planning and equipment procurement. In view of overall supportive activities, time and effort was expended in developing laboratory data acquisition systems; fabricating additional creep testing equipment; generating users manuals for the finite-element computer codes to complement their earlier documentation $^{11-12}$; and hosting a workshop/review meeting for modeling subcontractors and. interested parties for the office of Waste Isolation (OWI). 13 


\section{GLOBAL REPOSITORY ANALYSES}

Thermal and thermoelastic analyses have been performed on various repository models. Generally, axisymmetric geometry is assumed with the repository represented by a disk of heat generating material. Subsequent failure potential analyses based on the thermally induced stress fields indicate zones or areas critical to the repository design. The failure on fracture potential is derived from a comparison, at. the same mean stress, of the calculated state of stress and the stress state at failure as defined by a parabolic Mohr-Coulomb failure envelope. Global types of analyses coupled with local types of analyses, which are primarily concerned with the stress and deformational behavior near the specific storage area, provide for more definitive analysis of the overall repository.

Analyses to date have considered dome salt ${ }^{14}$, bedded salt ${ }^{14}$, and granitic models. Single level repositories have been considered exclusively; however, the extension to multilevel repository models is rudimentary. Ten-year old spent fuel and high level waste have been considered over a rarge of gross thermal loadings (GTL's) from 25 to 150 $\mathrm{kw} / \mathrm{acre}$. The coefficient of lateral earth pressure, $K$, was chosen as one (lithostatic condition) for the salt models and for other rock types $K$ ranged from $I / 3$ to 2 . In general, the temperature rise and displacements depend linearly on the GTL (in certain cases the thermal conductivity was considered to be temperature dependent; with the larger values always resulting from the $150 \mathrm{kw} /$ acre spent fuel GTL. Comparative timewise temperature behavior and displacement behavior are given in Figures 1 and 2 for various models and materials.

Representative bedded and dome salt models consiaered a 2,000 foot deep repository with a diameter of 7,000 feet. These models were analyzed for spent fuel GTL's of 25, 50, 75, and $150 \mathrm{kw} / \mathrm{acre}$. Peak displacements occurred at approximately 1,000 years and 200 years for the spent fuel GTL's and the high level waste GTL, respectively, with the high level waste producing one-third the displacement of the spent fuel. The difference in surface displacements between the bedded and dome salt models was negligible. No significant advantage or disadvantage was noted in comparing the bedded and dome salt models. However, the dome salt model had a slightly greater potential for 


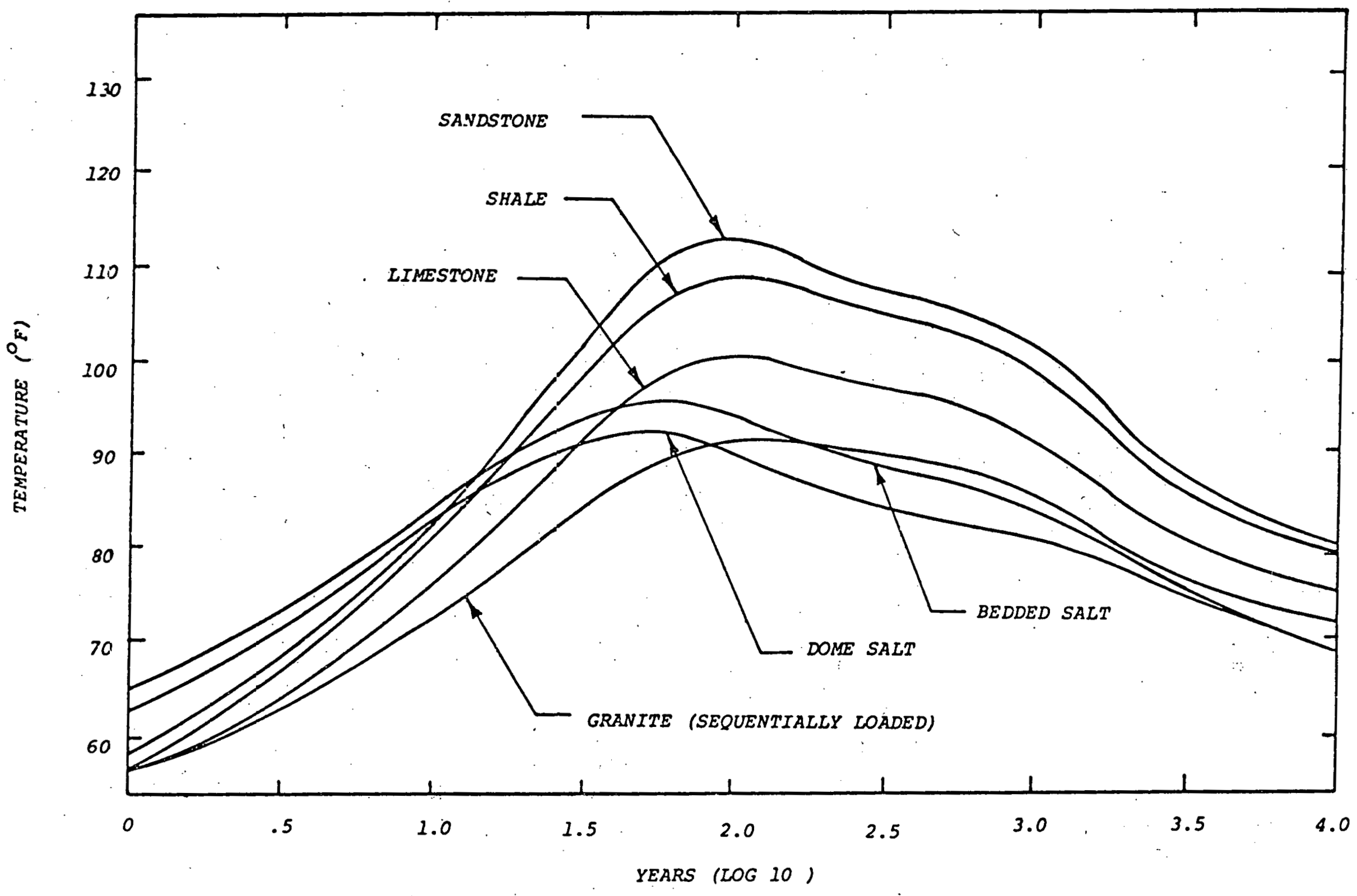

Figure 1. Comparison of Temperatures at the Outer Radius of Various Repository Models subjected to a Gross Thermal Loading of $50 \mathrm{KW} /$ Acre of $10 \mathrm{Year}$ Old Spent Fuel. 


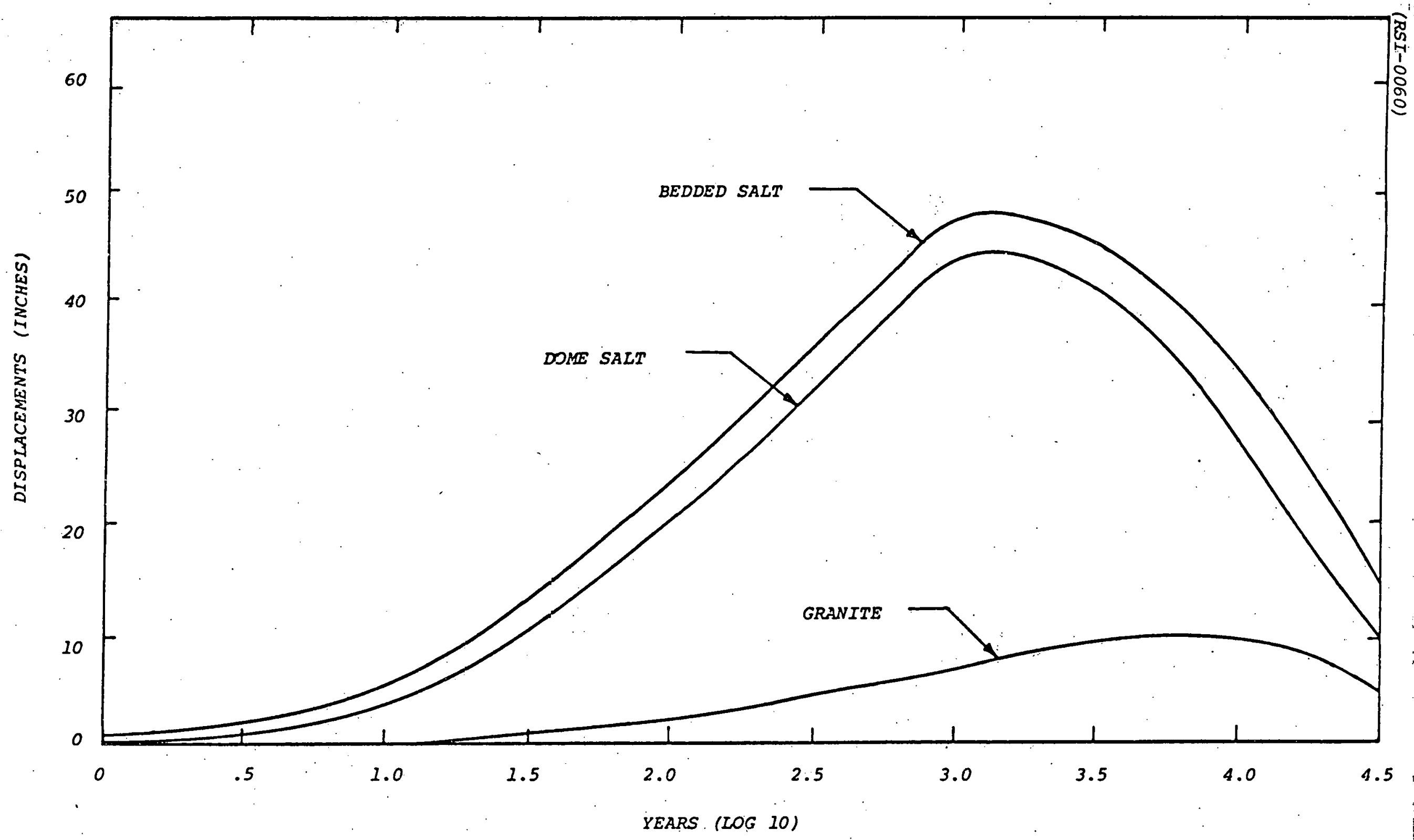

Figure 2. Vertical Surface Dispiacemts at the Repository Centerline for Various Models Subjected to a Gross Thermal Loading of $50 \mathrm{KW} / A c r e$ of 10 Year Old Spent Fuel. 
failure above the repository area. This was induced by the material stringers (e.g. thin cap rock layer above the dome) and the material mode1. Subsequent analyses assuming that all materials had identical Poisson's ratios and thermal expansion coefficients showed a reduction of the potential for failure. An analytical investigation of repository ventilation illustrated a significant reduction in the repository temperatures. Due to the purely elastic material models and the absence of any ventilation, it is felt that the overall analysis was of a conservative nature.

The granitic model involved a 10,000 foot diameter repository situated at a depth of 3,000 feet, with a centrally located shaft pillar 600 feet in diameter. GTL's considered for the model consisted of 50, 100, and $150 \mathrm{kw} /$ acre of ten-year old spent fuel and high level waste. Two in situ stress conditions were considered (i.e. $K=1 / 3$ and 2). The maximum vertical surface displacement for the granitic model was approximately 10 inches at 5,000 years for a GTL of $50 \mathrm{kw} / a c r e$ of spent fuel. The significantly lower displacements in the grantic model when compared with the dome and bedded salt models are expected as the thermal expansion coefficient of granite is roughly $20 \%$ of that for rock salt.

The potential for failure is greatest at about 200 years in the shaft pillar and at the outer boundary of the repository at the repository level for both values of $K$ with a speul fuel aTL of $150 \mathrm{kw} /$ aoro. The two areas are adjacent to the heat generating material and consequently have the largest thermal gradients. This phenomenon vanished for a GTL of $50 \mathrm{kw} /$ acre, but did appear to a limited extent for the $100 \mathrm{kw} / \mathrm{acre}$ loading.

For the granitic model, a sequential burial scheme was developed to more accurately represent the waste emplacement process. The loading scheme initiates at the outer repository radius and progresses inward for a twenty-five year period at which time the repository is considered to be 'full'. The effects of the sequential burial are noted early in time. Thermal gradients are generated through the repository. These gradients are less severe than other areas and essentially disappear after 1,000 years of heating. 
3. STRUCTURAL ANALYSIS OF PROGRESSIVELY MINED SOLUTION CAVITIES IN SALT

Investigations of the time-dependent behavior of spherical solution cavities ${ }^{10}$ raised a number of questions requiring further examination. Among these questions were the influence of the premining horizontal in situ stress state and the influence of the cavity shape on the stress and deformation about the cavity. For that matter, the cavity shapes are continually changing with time throughout the mining process and gradually evolve to the final configuration. The objective of this particular analysis ${ }^{15}$ was to address the problem of the time-dependent behavior of progressively-mined cavities of different shapes under arbitrary initial stress fields.

To facilitate this analysis, the spherical cavity was initially analyzed and compared with other elastic ${ }^{16}$ and viscoelastic ${ }^{17}$ solutions. subsequently, the spherical cavity was assumed to be excavated in a sequence of five mining passes occurring at times $0.0,0.25,0.5,0.7$, and 0.9 years, with the first excavation occurring in an initial lithostatic stress field. The washing fluid pressure was also included in the analysis. The finite-element mesh used in the analysis, illustrating the mining sequence, is depicted in Figure 3 . The horizontal stress after excavation is illustrated in Figure 4. These results indicate the importance of the excavation sequence on the cavity behavior. As seen in Flgure 4, opposed to one instantaneous excavation, the horizontal stress is less symmetric and actually higher at the top of the cavity. This is due to the fact that during excavation, the stresses near the bottom have experienced creep relaxation.

The previous problem was also examined for values of $K$ equal to 2/3, 1, and 4/3. One difference was that following the final excavation, the fluid was assumed to be evacuated. The creep behavior is extremely sensitive to relatively small changes in the value of $K$. For example, when the premining horizontal stresses are $4 / 3$ of the vertical stress, the upward displacement at the bottom of the cavity after three years following final excavation is an order of magnitude greater than the corresponding displacement for the case in which the premining horizontal stresses are $2 / 3$ of the vertical stress. It is interesting to note that for the case $k=4 / 3$, the entire cavity rises. In all three cases, the 


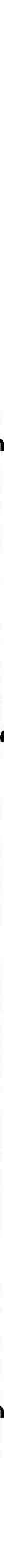

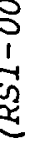




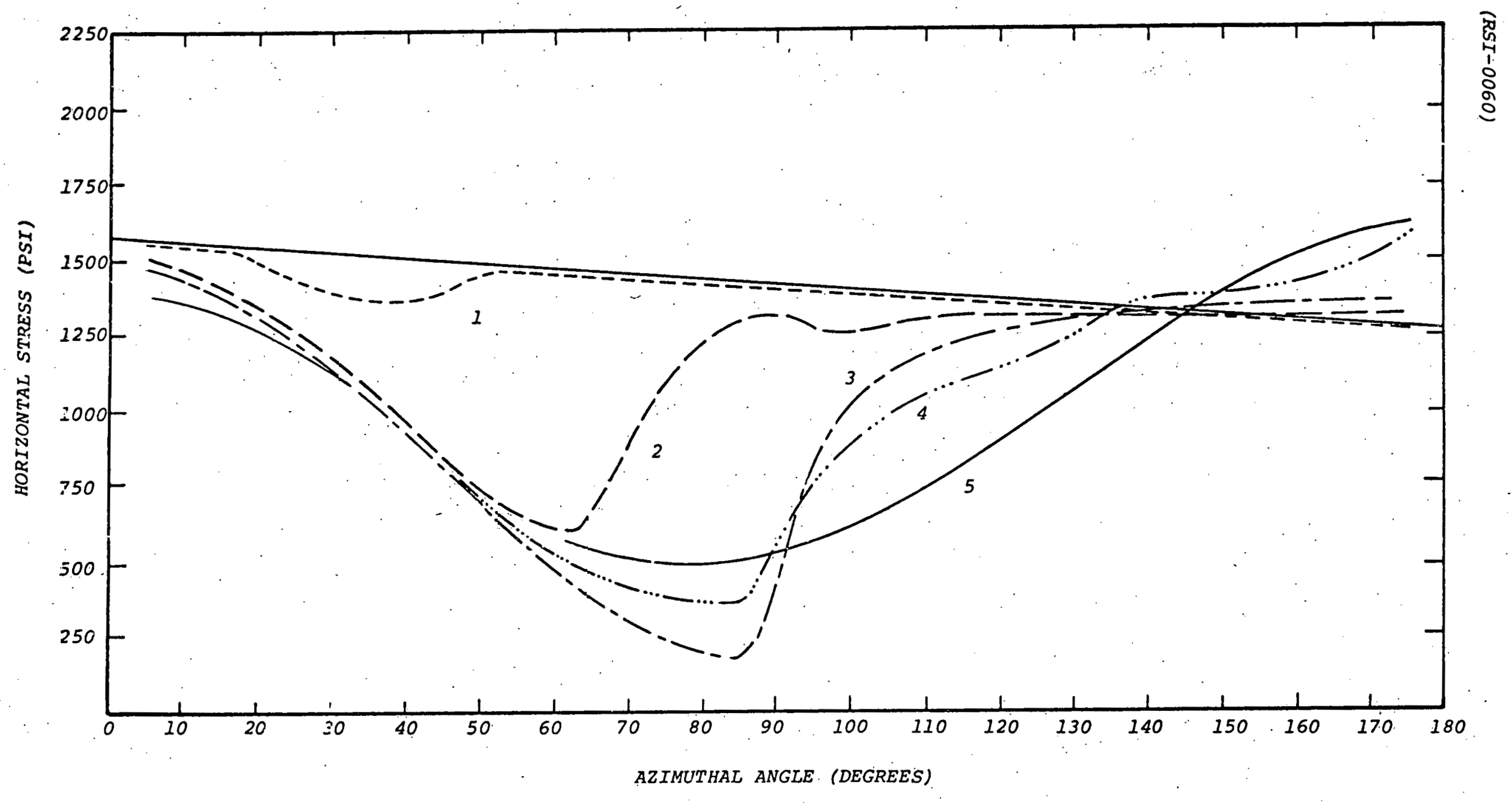

Figure 4. Influence of Excavation on Horizontal Stress Around a Spherical Cavity. 
side of the cavity moved in and the bottom of the cavity moved up with time. The top of the cavity however rose when the horizontal stresses were greater than the vertical stress. These observations illustrate just how important an initial assessment of the premining state of stress is.

Spherical, oblate spheroid, and prolate spheroid shapes were the configurations chosen to evaluate the cavity shape on creep behavior. A Iithostatic stress field was chosen as the initial state of stress for the models. Similar excavation and fluid evacuation sequences were followed as before. As would be expected, the stress distribution was smoothest for the sphere. The most severe stress gradients appeared near the equator of the oblate spheroid. The effective stress (i.e. $\left(3 J_{2}\right)^{\frac{3}{2}}$ where $\mathrm{J}_{2}$ is the second invariant of the stress deviator), which is essentially the driving force in the creep, was similar for all three shapes with the oblate spheroid showing the largest deviation from the other two.

For an initial lithostatic stress state, it appears that the oblate spheroid is the least preferred shape with the sphere being the most desirable with respect to the percent of closure. 
4. STRUCTURAL SIMULATION OF THE ROOM-AND-PILLAR MINING SYSTEM AT THE JEFFERSON ISLAND SALT MINE

Analysis of the behavior of the Diamond Crystal Salt Company Jefferson Island (JI) Mine located in Southwestern Louisiana involved several items. These items included a parametric study to assess the influence of upper level mining on the level of interest (the 1,500 foot level); consideration of the time-wise deformational behavior of a particular room-and-pillar, and comparison of the results with experimental information obtained by the rock mechanics personnel of the mine.

In order to determine the influence of the 1,300 foot level (upper level) on the 1,500 foot level, three plane strain models were selected that represented single room/single pillar configurations extracted from an infinite row of rooms and pillars. The first model considered the upper level rooms to be directly above the lower level rooms; the second model considered the upper level rooms to be above the lower level pillars; and the third model excluded the upper level. Three lateral earth pressures, $K$, or initial in situ stress states of $0.5,1$, and 1.5 were examined for each of the three models. Comparisons of the elastic stress fields about the lower mining level were made through examination of contours of the effective stress, $\left(3 \mathrm{~J}_{2}\right)^{\frac{3}{3}}$. The contours were essentially identical for each of the models when compared at the same In sllu sliess state. Thug, it was concluifer that the influence of the upper level mine was negligible on the lower level of the mine with regard to the state of stress at the points of interest. However, the horizontal pillar displacements were found to change sign at a point in the pillar dependent on the value of $K$. This does not necessarily mean separation, but rather the existence of a point of zero displacement.

A parametric analysis of the room height revealed increasing effective pillar stress with height. Without performing an inelastic analysis, the thirty-foot room height was felt to be optimum. These analyses were performed assuming axisymmetric geometry and resulted in higher effective pillar stresses. Therefore, since the effective stress is essentially the 'driving force' in the creep formulation, the more conservative viscoelastic analysis would be derived from the axisymmetric geometry. 
I

A viscoelastic analysis was performed in axisymetric geometry and compared to the roof-floor closure measured in the mine. Due to the complicated geometry of the mine and the fact that excavation continued during the experimental data acquisition, the early predicted values do not compare favorably. However, after one year, the predicted displacements and the measured values compare quite well. 


\section{SHORT-TERM ROOM DEFORMATION IN SALT REPOSITORIES}

Short-term (less than 25 years) room closure is an important element in consideration of retrievability of nuclear wastes isolated in salt repositories. Rock salt is known to be a viscous material whose rate of deformation increases under elevated temperatures. Therefore, the presence of the heat generating wastes may result in adverse room configurations depending on the magnitude of the overall thermal loading and temperature fields generated.

Table 1 presents a general description of the various plane strain models analyzed along with the depth, thermal loadings, and roof-floor closure associated with each model. Also included is a graphic comparison of the room and pillar configurations for each of the models. Twentyfive year analyses were performed for the ER2O and ER4O models and a five year analysis for the ER2.5 model.

A power law creep formulation was utilized in these analyses; the general formulation for the creep strain, $\varepsilon_{i j^{\prime}}^{c}$ is given in equation 1 .

$$
\varepsilon_{i j}^{c}=1.37 \times 10^{-37}\left(\sqrt{3 J_{2}}\right)^{2} \frac{3}{2} s_{i j} t^{0.4} T^{9.5}
$$

where:

$$
\begin{aligned}
J_{2} & =\text { second invariant of the stress deviator (psi) } \\
s_{i j} & =\text { deviatoric stress (psi) } \\
t & =\text { total time (hrs.) } \\
T & =\text { temperature }(\mathrm{K}) .
\end{aligned}
$$

As can be seen, the nonlinear dependence of the creep strain on temperature is quite important. In fact, as the pillar heats, an acceleration in deformation is noted. The ER4O model, which has the largest pillar height to width ratio, deformed rather uniformly; whereas, the ER25 and ER2O models had substantially greater shortening of the pillar at the rib than at the pillar centerline. This is partially attributable to the fact that the pillar in the ER4O model heated more uniformly than in the other models. Figure 5 illustrates the final deformational pattern of the model configurations. 
TABLE 1. DESCRIPTION OF GEOMETRIC MODELS AND MAXIMUM ROOF-FLOOR CLOSURE

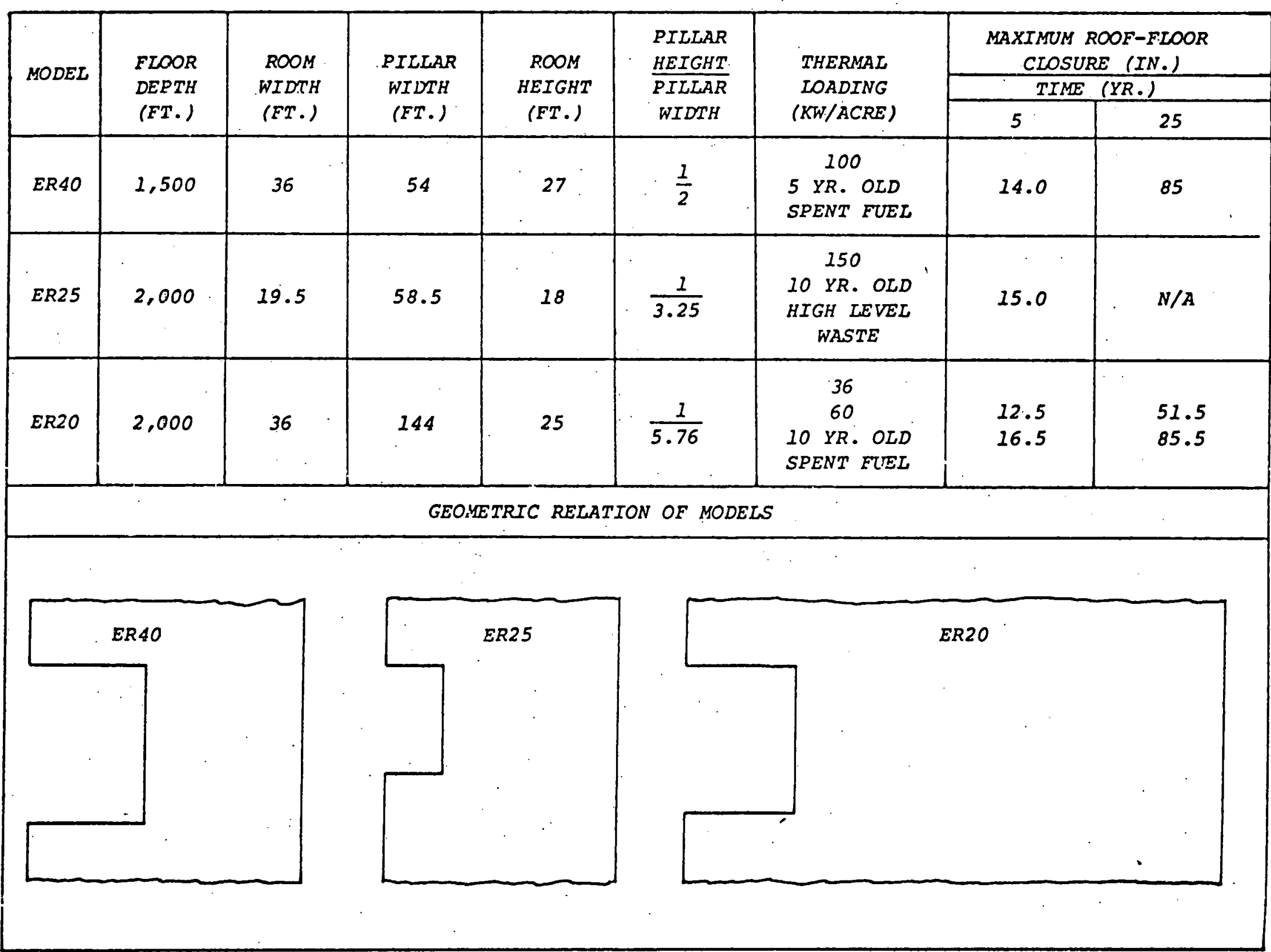




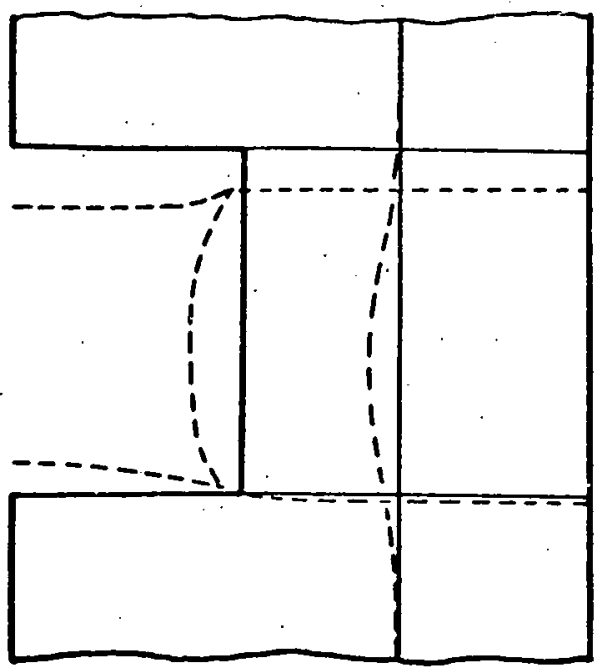

(a) ER40 Model At 25 Years.

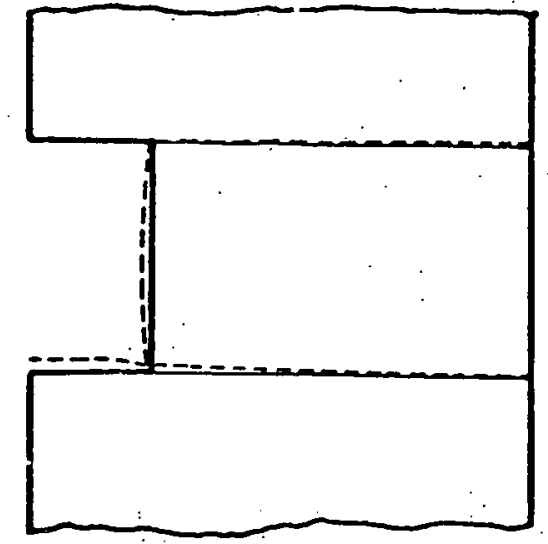

(b) ER25 Model At 5 Years.

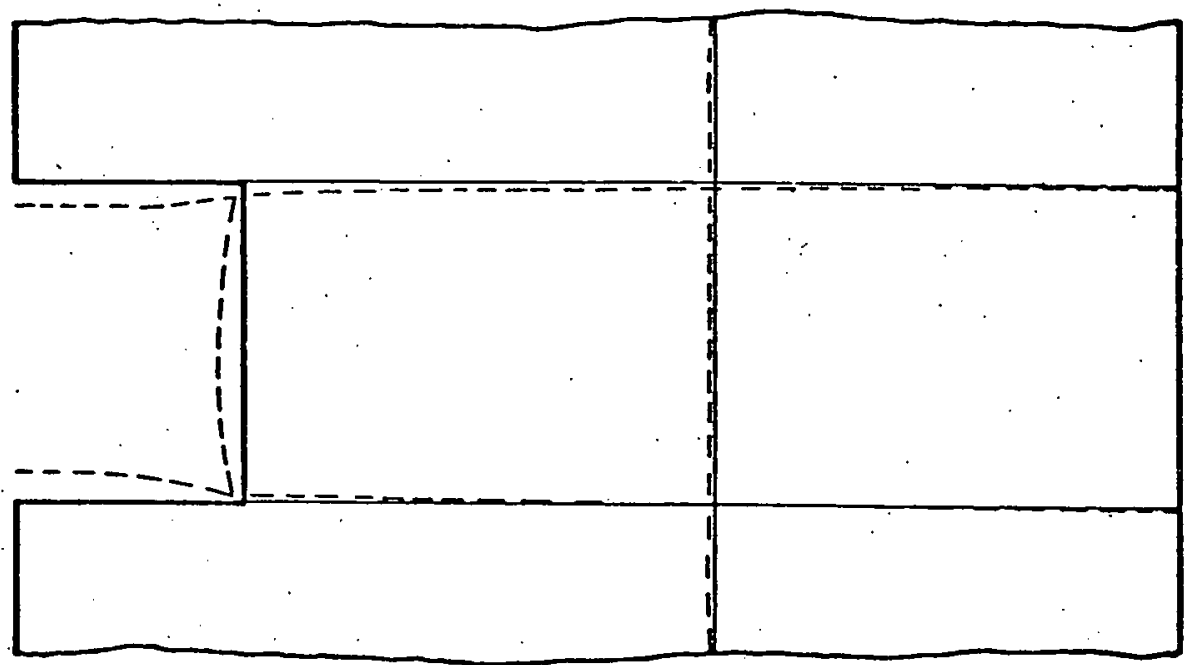

(c) ER20 Model At 25 Years (60. KW/Acre).

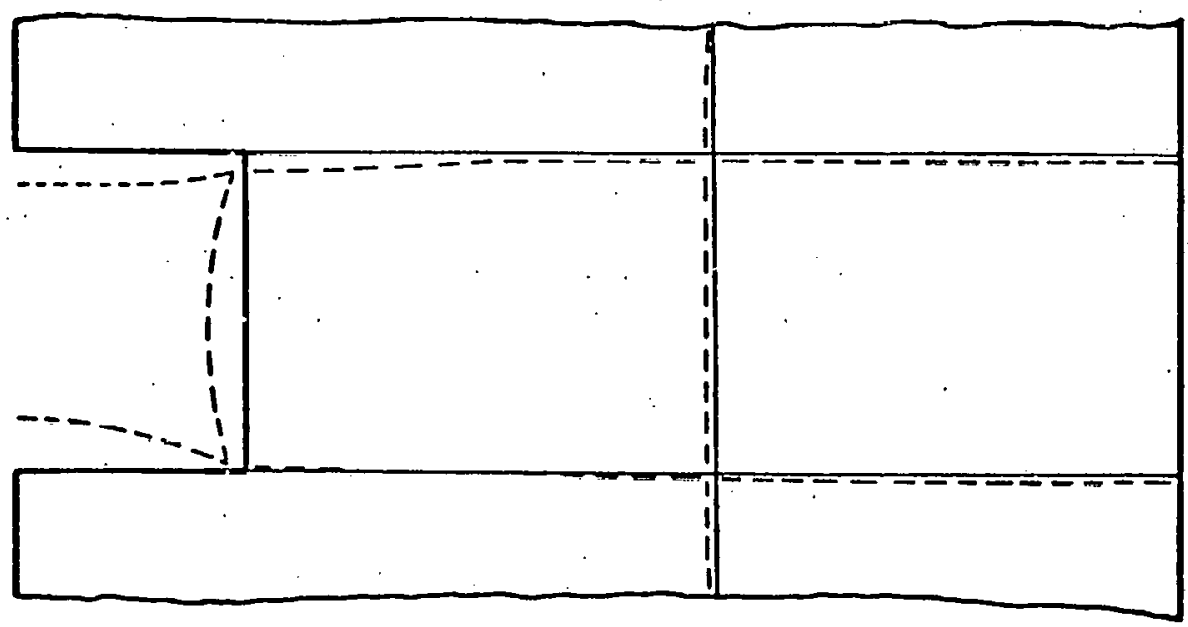

(d) ER20 Model At 25 Years $(36 \mathrm{KW} /$ Acre).

Figure 5 . Final Thermo/Viscoelastic Deformational Patterns for the Various Models (See Table 1). 
Additional analuses were performed to assess the general nature of the thermal and viscous effects on the room behavior. Among these analyses were thermoelastic, purely viscous, and thermo/viscoelastic without temperature dependence included in the creep formulation. In general, the thermoelastic analyses resulted in expansion without room closure. purely viscous analyses resulted in closures equal to approximately $20 \%$ of those presented. Neglecting temperature dependence in the creep formulation resulted in closures equal to approximately $30 \%$ of those presented. The basic conclusion from these results is that, due to the temperature sensitivity of rock salt, the magnitude of the induced temperature field is probably more critical than the expected thermal gradients. 
6. QUASI-STATIC AND CREEP TESTING

Since October of 1976, testing of natural rock salt has been completed on Jefferson Island (JI) dome salt and Lyons, Kansas bedded salt, and another suite of testing is in progress on fivery Island (AI) dome salt. Subsequent to completion of the respective test programs for the Jefferson Island and Lyons, Kansas (LSMF) salt, deformed and .. undeformed specimens were examined by Dr. Neville L. Carter to ascertain the deformational mechanisms of the salt from each site.

Testing of Lyons salt entailed preparation of a limited number of specimens which were collected several years ago (approx. 1972) from the Lyons, Kansas salt mine floor in the proximity of Project salt vault (PSV) activity. Experimentation was initiated in 1976 and completed in 1977 upon expiration of the core available for testing. The test program primarily developed constitutive relationships of triaxial and unconfined quasi-static compressive behavior. Tests were conducted at both room temperature $\left(21^{\circ} \mathrm{C}\right)$ and $100^{\circ} \mathrm{C}$; measurements of strain we re accomplished through the use of direct electrical resistant strain gauge readings and indirectiy through the use of differential displacement transducers. In addition to quasi-static deformational measurements, several creep tests were run at various temperatures and confining pressures. Data generated both under quasi-static and creep conditions were compared to test data reported in ORNL $4555^{18}$ as a result of test programs associated with PSV. General stress-strain relationships and.creep behavior as obtained in this limited testing program were used in addition to the data in ORNL 4555 to formulate material properties for fintte-element modeling of PSV.

The test program supporting the structural simulation of JI was conducted at room temperature and involved evaluation of triaxial quasistatic compressive strength and deformational characteristics, triaxial creep behavior and size effects under uniaxial compression. To evaluate the two formerly mentioned properties, two inch diameter specimens were tested. Results obtained include quasi-static mechanical properties, creep behavior and a parabolic failure envelope. Creep behavior was defined by the power law given in equation 2 . 


$$
\varepsilon_{a}=3.383 \times 10^{-13} t^{0.377} \sigma^{2.52}
$$

where:

$$
\begin{aligned}
& \varepsilon_{a}=\text { axial strain } \\
& t=\text { total time (sec.) } \\
& \sigma=\text { differential stress (psi) }
\end{aligned}
$$

Further discussion of the materials properties may be found in a report 19 which has been completed and submitted to OWI for review.

The uniaxial testing of Jefferson Island dome salt was completed in May, 1977. A total of 128 specimens having nominal diameters of 2, 4, 6,8 , and 12 inches and length-to-diameter $(L: D)$ ratios of $0.5,1,1.5$, and 2 were tested in quasi-static compression. Approximately 80 percent of these specimens were tested with the use of strain gauges to determine their mechanical properties. Also included in the testing program were indirect tensile strength tests on 52 specimens with approximately $L: D$ ratios of 0.5 . The six-inch diameter specimens included core which was cut both vertically from the mine floor and horizontally from the rib. Test results indicate an absence of either strength or elastic anisotropy. The salt exhibits an initial loading modulus of the order of $1 \times 10^{6}$ psi from a stress level of 0 to about 750 psi. From an unloading-reloading cycle at a stress level of approximately 2000 psi, a modulus of the order of $3 \times 10^{6}$ psi was observed.

Whilc very little cllanye In modulus was observed with a change in specimen diameter, a slight decrease in modulus was noted with an increase in $L: D$ ratio. The principal strain ratio observed from the unload-reload cycle was of the order of 0.34 and no apparent dependence of the principal strain ratio on sample size or geometry was observed. . The unconfined compressive strength of this salt increases in an exponential manner with a decrease in $L: D$ ratio. Strength of the specimens with a 2:1-L:D ratio ranged from about $2500 \mathrm{psi}$ to $4200 \mathrm{psi}$. While no significant change in compressive strength between 4 and 12 inch diameter specimens was observed, there appears to be a critical strength reduction in specimens with diameters less than four inches. 
An axisymetric finite-element analysis was conducted for specimens having $L: D$ ratios of $0.5,1,1.5$, and 2 loaded between loading platens. Two cases were investigated using an elastic analysis. First, the specimens were modeled as loaded between steel platens to analyze the elastic mismatch between the loading platens and specimen ends. The specimens were then modeled as loaded between platens having the same elastic properties as the specimen to analyze the effect of platen overhang (mismatched diameters). From the results of these analyses, the stress nonuniformities caused by platen overhang are potentially greater than the nonuniform state of stress caused by the elastic mismatch of the platens and specimen ends. The properties obtained from the unloadreload cycle of the unconfined compressive tests were used for both cases. Specimen displacements obtained from the mismatched elastic properties case at a 1000 psi stress level compared favorably to the strain gauge results from the actual tests.

In order to obtain, a fundamental physical understanding of mechanical results of tests on natural rock salt from JI and Lyons, the nature of the deformational processes was studied by $D r$. Neville $L$. Carter. To this end, Carter has analyzed selected specimens from Lyons, Kansas bedded salt, and Jefferson Island domal salt deformed experimentally in various modes under the direction of Mr. Francis $D$. Hansen at RE/SPEC InC. Undeformed, as-cored material was first examined carefully by optical techniques, and preferred crystal oxientations (fabrics) were determined using universal stage techniques. A similar procedure was uced for the mast highly deformed specimens to assess changes in fabric induced by deformation; and petrographic techniques were used to determine the nature of the deformation. All specimens, deformed to intermediate axial strains, were analyzed carefully by petrographic techniques alone which are sufficient to characterize the deformation mechanisms. Finally, the results of these analyses have been correlated will the mechanical data of Hansen and have thus provided a sound physical basis for interpretation of these data. The correlation so obtained should contribute in an important way to attempts at finite-element modeling of the time-dependent behavior of storage roulis and pillars in rock salt repositories. 
During the final portion of this year, tests have been initiated to develop constitutive relations for rock salt from $A I$ in order to facilitate an a priori assessment of the deformations anticipated during a scheduled in situ heater experiment. The test matrix encompasses triaxial compression at confining pressures up to 5,000 psi and temperatures up to $100^{\circ} \mathrm{C}$, and triaxial creep over the same pressure and temperature range at several differential stress levels. Testing to date has expired the core available and has generated basic data for preliminary evaluation of these properties. Subsequent to initiation of field activities, extended testing of $A I$ core will fill out a complete matrix of tests and result in a comprehensive evaluation for input data for analyses. 
7. DESIGN FABRICATION AND IMPLEMENTATION OF CREEP TESTING APPARATUS

Fabrication and implementation of four large (accommodating fourinch diameter specimens) creep testing apparatus began in May, 1977 upon receipt of technical drawings from owI. Pursuant to receipt of drawings, technical review was initiated. Due to the size and complexity of the machining requirements, the job of fabrication had to be let to a large machine shop. Solicitation of bids also began in May with bids being submitted by two firms from the Minneapolis, Minnesota area, and two from the Denver, Colorado area. The successful bidder was chosen in July, 1977.

Material purchases began about August 1, 1977 and machining began on August 5, 1977. The RE/SPEC work effort which encompasses design of mechanical and hydraulic machine components also began in August. The basic machining is nearly 95\% complete; this work includes machining, heat treating, and acquiring shop supplied items. Assembly of the mainframes is scheduled for the end of september and is estimated to require two weeks. The mainframes are scheduled for delivery, one at a time, beginning in the first half of october and continuing into November. In house assembly, purchased parts delivery, acquisition system delivery and setup, servo system design and checkout, and associated work to bring the machines to "on line". status will require several additlonal months.

A majority of the accessories for the mainframe, including high pressure valves and fittings, hydraulic pumps, electrical transducers, hydraulic gauyes, accumulators, heaters, and other items are being ordered. A data logger/acquisition system has been selected and purchased with expected delivery about October 1, 1977. Calibration of the entire system will require additional months of effort. 


\section{TECHNICAL ASSISTANCE TO OWI ON IN SITU HEATER EXPERIMENT DESIGN}

The primary aspect of effort in this task during the past fiscal year has been in reviewing the design drawings as prepared by union Carbide Corporation, Nuclear Division/Engineering (UCC-ND, Engineering). A series of construction, fabrication, and installation drawings have been developed covering items such as the heaters, sleeves, associated instrumentation, data acquisition systems, and special tools and facilities. $R E / S P E C$, as the ultimate installer, critiqued each item as regards 1) feasibility of installation, 2) suitability of the component in performing its function, and 3) possible refinements to improve either 1) or 2). The details are now complete and UCC-ND has begun or finished fabrication of most of the items.

A trip to Avery Island Mine by several engineers from OWI, UCC-ND (Engineering), and RE/SPEC was made in August, 1977 for purposes of final inspection of the facility site within the mine. The inspection prompted the shifting of two of the three sites to take advantage of a higher roof. The boundaries of the area were also defined such that Akzona/ International salt Co. could complete the cleanup of the site in preparation for the installation. 


\section{INSTALLATION OF AN IN SITU HEATER EXPERIMENT}

The actual installation of the heater experiment at the Avery Island Mine was not accomplished during the fiscal year. In fact, the instaliation was not even begun due to the unanticipated delay in negotiating the right-of-entry agreement with Akzona/International Salt Co. and the Avery Island owners. These rsegotations have, however, been completed. All materials, instruments, and equipment for immediate use in the installation have been procured and to a major extent been through "shake-down testing" where appropriate. Two underground type drills have been obtained to perform the drilling of the various sized holes required in the experiment in an expedient manner. The vibrating wire stressmeters have been fabricated by IRAD Inc. and are currently being calibrated in the RE/SPEC laboratory for use in salt at elevated temperature. Having accomplished these tasks, the preliminary aspects are complete, and installation will begin early October, 1977. 
10. REVIEW/WORKSHOP ON THE ROCK MECHANICS ASPECTS OF RADIOACTIVE WASTE DISPOSAL IN GEOLOGICAL FORMATIONS

RE/SPEC Inc. organized and hosted a rock mechanics workshop for OWI in Denver, Colorado on December 16 and 17, 1976. The meeting was scheduled for contractors, consultants, potential participants, and other interested parties to: (1) review:the progress and status of supported rock mechanics programs, (2) outline the overall OWI waste disposal programs, goals and objectives, and (3) determine the rock mechanics objectives and program elements required in (2). An advisory panel consisting of Dr. Neville L. Carter, Dr. Richard E. Goodman, and Mr. Robert $H$. Merrill was selected to be responsible for distilling the discussions into recommendations and an associated report.

Presentations were given by OWI, Sandia Laboratories, RE/SPEC InC., Science Applications Inc., and the University of Minnesota. ${ }^{13}$ The overall meeting was successful with over fifty participants providing constructive criticism and discussion. A summary of the review meeting with recommendations is provided in the report prepared by the advisory panel 20 . 


\section{FINITE-ELEMENT COMPUTER CODE USER MANUALS}

As requested by OWI, user's manuals $s^{21-22}$ were prepared for the $R E / S P E C$ finite element heat transfer and thermo/viscoelastic stress analysis computer codes. The manuals describe the required data input for various classes of problems and utilize example problems illustrating mesh and data input preparation with accompanying solutions. Generally, the codes are continually changing and being modified; thus, new versions currently exist. Modified versions usually require the same data input, but include internal methods of handling different types of problems, the solution procedure, or possibly the constitutive relation in the case of viscous behavior. 


\section{LIST OF REFERENCES}

1. Gnirk, P. F., Callahan, G. D., and Hovland, H.: "Thermoelastic Analysis of Waste-Container Sleeve", Technical Memorandum Report RSI-0008, prepared by RE/SPEC InC. for Union Carbide Corporation, Nuclear Division, Oak Ridge National Laboratory under subcontract. No. 3706 (January 7, 1974), ORNL/SUB-3706/5.

2. Pariseau, W. G.: "Thermoelastic/Plastic Analysis of the waste Container Sleeve: I. Initial Estimates of loading on the sleeve", Technical Memorandum Report RSI-0010, prepared by RE/SPEC Inc. for Union Carbide Corporation, Nuclear Division, Oak Ridge National Laboratory under Subcontract No. 3706 (Apri1 22, 1974), ORNL/SUB-3706/6.

3. Pariseau, w. G.: "Thermolastic/Plastic Analysis of WasteContainer Sleeve: II. Influence of Large Displacements on Sleeve Loading", Technical Memorandum Report RSI-0017, prepared by RE/SPEC Inc. for Union Carbide Corporation, Nuclear Division, Oak Ridge. National Laboratory, ORNL/SUB-4269/1 (March 21, 1975).

4. Pariseau, W. G.: "Thermoelastic/Plastic Analysis of WasteContainer Sleeve: III. Influence of Salt Strength on Sleeve Loading", Technical Memorandum Report RSI-0018, prepared by RE/SPEC Inc. for Union Carbide Corporation, Nuclear Division, Oak Ridge National Laboratory, ORNI,/SUB-4269/2 (March 21, 1975).

5. Pariseau, W. G.: "Thermoelastic/Plastic Analysis of WasteContainer sleeve: IV. Air Gap Influence on Hole Closure", Technical Memorandum Report RSI-0019, prepared by RE/SPEC. Inc. for Union Carbide Corporation, Nuclear Division, Oak Ridge National Laboratory, ORNL/SUB-4269/3 (March 21, 1975).

6. Callahan, G. D. and Ratigan, J. L.: "Thermo/Viscoelastic Analysis of the Waste-Container Sleeve:. I. Time-Dependent Salt Loading on the Sleeve and Closure of the Drillhole", Technical Memorandum Report RSI-0020, propared by RE/SPEC Inc. for Union Carbide Corporation, Nuclear Division, Oak Ridge National Laboratory, ORNL/SUB-4269/4 (June 30, 1975).

7. Callahan, G. D. and Ratigan, J. L.: "Thermo/Viscoelastic Analysis of the Waste-Container sleeve: II. Stress and Displacement Fields for the Room-and-Pillar Configuration", Technical Memorandum Report RSI-0021, prepared by RE/SPEC Inc. for Union Carbide Corporation, Nuclear Division, Oak Ridge National Laboratory, ORNL/SUB-4269/5, (June 30, 1975).

8. Callahan, G. D., Ratigan, J. L., Russell, J. E., and Fossum, A. F.: "Heat Transfer Analysis of the Waste-Container Sleeve/Salt Configuration", Technical Memoranaum Report RST-0023, prepared for Union Carbide Corporation, Nuclear Division, Oak Ridge National Laboratory, ORNL/SUB-4269/7 (March 31, 1975). 
9. Hansen, F.D.: "Experimental Consolidation of Granulated Rock Salt with Application to Sleeve Buckling", Technical Memorandum Report RSI-0044, prepared by RE/SPEC InC. for Union Carbide Corporation, Nuclear Division; Oak Ridge National Laboratory, ORNL/SUB-4269/21, (Apri1 5, 1976).

10. Fossum, A. F.: "Structural Analysis of salt Cavities Formed by Solution Mining: I. Method of Analysis and Preliminary Results for Spherical Cavities", Technical Memorandum Report RSI-0043, prepared by RE/SPEC Inc. for Union Carbide Corporation, Nuclear Division, Oak Ridge National Laboratory, ORNL/SUB-4269/19, (January 15, 1976).

11. Callahan, G. D.: "Documentation of the Heat Conduction Code TRANCO", Technical Memorandum Report RSI-0037, prepared by RE/SPEC Inc. for Union Carbide Corporation, Nuclear Division, Oak Ridge National Laboratory, ORNL/SUB-4269/15 (August 8, 1975).

12. Callahan, G. D.: "Documentation of the Thermo/Viscoelastic Code TEVCO" . Technical Memorandum Report RSI-0039, prepared by RE/SPEC Inc. for Union Carbide Corporation, Nuclear Division, Oak Ridge National Laboratory, ORNL/SUB-4269/17, (September 30, 1975).

13. Preprints of the Review/Workshop Meeting on the Rock Mechanics Aspects of Radioactive Waste Disposal in Geological Formations, Cherry Creek Inn, Denver, Colorado (December $16 \& 17,1976)$. Organized by RE/SPEC Inc. for the Office of Waste Isolation operated by Union Carbide Corporation, Nuclear Division, Y/OWI/TM-49 (November, 1977).

14. Callahan, G. D. and Ratigan; J. L.: "Thermoelastic Analyses of Spent Fuel Repositories in Bedded and.Dome Salt", Technical. Memorandum Report RSI-0054, prepared by RE/SPEC Inc. for Office of Waste Isolation operated by Union Carbide Corporation, Nuclear Division, Y/OWI/SUB-77/22303/4, (May 4, 1977).

15. Fossum, A. F.: "Structural Analysis of Salt Cavities Formed by Solution Mining: II. Time-Dependent Behavior of ProgressivelyMined Cavities of Different Shapes under Arbitrary Initial Stress Fields", Technical Memorandum Report RSI-0051, prepared by RE/SPEC Inc. for Office of Waste Isolation operated by Union Carbide Corporation, Nuclear Division, Y/OWI/SUB-77/22303/2, (January 28, 1977).

16. Timoshenko, S. and Goodier, J. N.: Theory of Elasticity, MCGraw-Hill, New York, p. 398; (1970).

17. Nair, K., Sandhu, R. S., and Wilson, E. L.: "Time-Dependent Analysis of Underground Cavities under Arbitrary Initial Field", Proc. loth Symp. on Rock Mech.; Austin, Texas, (1968).

18. Bradshaw, R. L. and MCClain, W. C. (Eds.), "Project Salt Vault: A. Demonstration of the Disposal of High-Activity Solidified Wastes in Underground Salt Mines", Oak Ridge National Laboratory, ORNL-4555 (Apri1 1971). 
19. Hansen, F. D.: "Case History Rock Mechanics Examination of the Jefferson Island Salt Mine: II. Laboratory Evaluation of Strength and Creep Deformation Characteristics of Dome Salt Under Confining Pressure", Technical Memorandum Report RSI-0057, prepared by RE/SPEC InC: for Office of waste Isolation operated by. Union Carbide Corporation, Nuclear Division, Y/OWI/SUB-77/22303/5, (June 10,.1977):

20. Carter, N. L., Goodman, R. E., and Merril1, R. H.: "Summary Review of Workshop on Radioactive Waste Disposal", office of Waste Isolation, Union Carbide Corporation, Nuclear Division, Y/OWI/TM-20, (February 7, 1977).

21. Callahan, G. D. and Fossum, A. F.: "Data Input Manual for RSI/TRANCO: A.Finite Element Heat Conduction Computer Program", Technical Memorandum Report RSI-0049, prepared by, RE/SPEC Inc. for Office of Waste Isolation operated by Union Carbide Corporation, Nuclear Division, Y/OWI/SUB-77/22303/1 (February 1, 1977).

22. Callahan, G. D. and Fossum, A. F.: "Data Input Manual for RSI/TEVCO: A Thermo/Viscoelastic Finite Element Computer Program", * Technical Memorandum Report RSI-0056, prepared by RE/SPEC Inc. for Office of Waste. Isolation operated by Union Carbide Corporation, Nuclear Division, Y/CWI/SUB-77/22303/6, (February 1, 1977). 